\title{
Oral Myiasis Treated with Ivermectin: Case Report
}

\author{
Elio Hitoshi SHINOHARA \\ Marcelo Zillo MARTINI \\ Humberto Gomes de OLIVEIRA NETO \\ André TAKAHASHI \\ Department of Oral and Maxillofacial Surgery, Conjunto Hospitalar do Mandaqui, SUS-SP, São Paulo, SP, Brazil
}

\begin{abstract}
Oral myiasis is a rare pathology and a risk to the patient's life. Conventional treatment is mechanical removal of the larvae (maggots) one by one, which is painful, distressing, and embarrassing both to the patient and to the dentist. We present a case report of a patient with cerebral palsy that had oral myiasis treated successfully with ivermectin. The use of this antibiotic in humans, its mechanism of action and indications are discussed.
\end{abstract}

Key Words: oral myiasis, ivermectin, parasitosis.

\section{INTRODUCTION}

Myiasis is a pathology caused by the presence of fly larvae in human or animal tissues that evolve to a parasite (1). There is a higher incidence in rural zones, infecting domestic animals such as cattle and pigs, as well as house pets such as dogs and cats, leading to economic loss and health injuries of these animals. They can attack humans, generally elderly people who are ill or debilitated $(2,3)$, especially in the tropics and third world countries $(4,5)$.

Clinically, they can be classified as primary and secondary. Primary myiasis is caused by biophagous larvae (feed on living tissue), which are common in cattle (called bicheiras) and are rare in humans. Nevertheless, when this occurs, it is generally serious and produced by Cochliomya hominivorax larvae ("varejeira" fly) that lays 20 to 400 eggs on exposed wounds. Hatching of the larvae occurs in $24 \mathrm{~h}$. The larvae are voracious and destroy integral tissues, and may cause serious hemorrhage and be life threatening. Secondary myiasis is that caused by the necrobiophagous flies (feed on dead tissue). This is a more common type and attacks patients with necrotic cavity lesions $(1,3)$.

We present a case report of a patient with oral myiasis treated successfully with oral ivermectin.

\section{CASE REPORT}

A 20-year-old Caucasian female patient with hypotonic cerebral palsy was referred to the Emergency Service of the Conjunto Hospitalar do Mandaqui, SUS/ SP, with a clinical history of larvae coming out of her mouth for one day. On clinical examination, the patient was found to be dehydrated, presenting an anterior swelling on the upper lip covered with integral skin and with signs of inflammation (Figure 1). Oral examina-

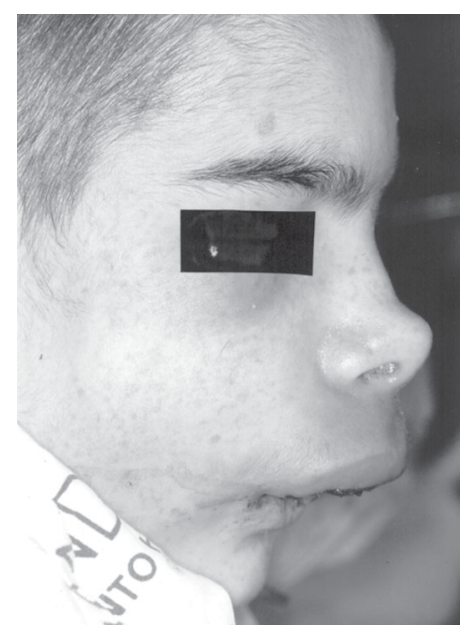

Figure 1. Appearance of patient at presentation. Note the anterior swelling on the upper lip. 
tion found a large number of larvae on the maxillary gingival labial sulcus, which were already destroying the gingival sulcus (Figure 2) near the nasal fossa. The computerized tomography showed the extension of tissue destruction (Figure 3). Hematological analysis was normal. Antibiotic therapy was started (1 g cefalotin, $i v$, every $6 \mathrm{~h}$ ), endovenous rehydration, and $6 \mathrm{mg}$ ivermectin was given orally, and repeated after $24 \mathrm{~h}$. On the first day, a marked decrease of the larvae (about $80 \%$ ) was observed, and the remaining larvae were immobile. Oral cleansing was made daily. After 3 days of hospitalization, there were no larvae in the patient's mouth and she was discharged. A parasitologist later identified the larva as the fly, Cochliomyia hominivorax.

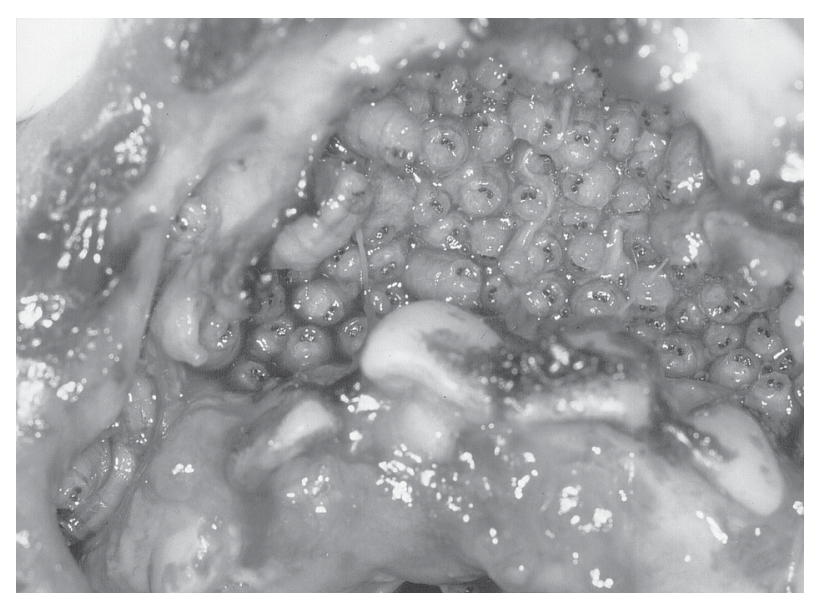

Figure 2. Photograph showing the maxillary gingival labial sulcus and the maggots.

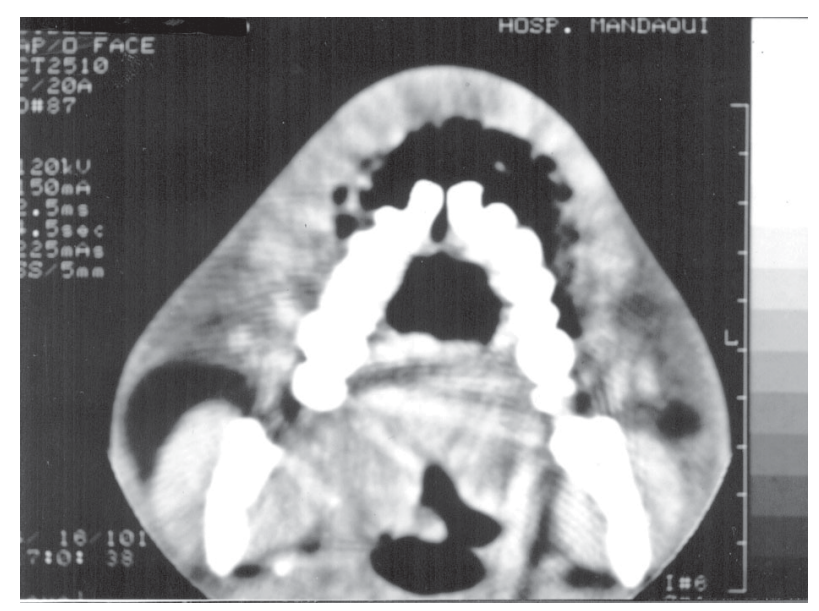

Figure 3. Computerized tomography with intravenous contrast of the maxilla. Gas bubbles are seen in the soft tissue in the anterior maxilla.

\section{DISCUSSION}

The standard treatment for myiasis is the manual removal, associated or not with topic and systemic asphyxiating drugs that force the larvae to come out. Various substances (ether, chloroform, olive oil, calomel, iodoform, phenol mixture) have been recommended for the treatment of myiasis; however, they have controversial results (6-8).

Ivermectin is a semi-synthetic macrolide antibiotic, isolated from Streptomyces avermitilis, and its use is well documented in large animals for the control of gastrointestinal and pulmonary parasitosis, for infestation by crab-louse and larva flies ("berne").

In 1993, ivermectin was reported to be safe for human use (9) and has been indicated for the treatment of filaria, scabies and strongyloidosis in humans $(9,10)$. Evaluating the use of oral ivermectin in human cavity infestations, Ribeiro et al. (3) reported that no patient presented alterations in hepatic or renal function after the oral ingestion of ivermectin. Thus, they concluded that it is a safe medication and presents neither side effects nor toxicity.

It is assumed that ivermectin blocks nerve impulses on the ending nerve through the release of gamma aminobutyric acid (GABA), linking to the receptors and causing palsy and death (11). Acetylcholine, which is the main peripheral neurotransmitter in mammalians, is not affected by ivermectin, maintaining a security margin when it is used at the recommended dose (3).

Recently, indications for topical and oral use for the treatment of myiasis have been found in the literature (12-15). Duque et al. (16) treated oral myiasis with $s c$ ivermectin, although 2 of the 3 cases were associated with phenol mixture (10\% creolin) as a local measure for the control of larvae.

Thus, the current literature describes ivermectin as an efficient and safe method of treatment of parasitosis and the present report describes its use in human oral myiasis.

\section{RESUMO}

Miíase bucal é patologia raramente descrita e que oferece risco de morte ao paciente. O tratamento convencional é a remoção mecânica das larvas uma a uma que é dolorido, constrangedor e repugnante tanto ao paciente quanto ao dentista. Apresentamos relato de caso de paciente portadora de paralisia cerebral que teve 
miíase bucal tratada com ivermectina. O uso deste antibiótico em humanos, o mecanismo de ação, assim como suas indicações são revisados.

\section{REFERENCES}

1. Rey L. Parasitologia. 2nd edn. Rio de Janeiro: Editora Guanabara Koogan; 1991.

2. Bhoyar SC, Mishra YC. Oral myiasis caused by diptera in epileptic patient. J Indian Dent Assoc 1988;58:535-536.

3. Ribeiro FAQ, Pereira CSB, Alves A, Marcon MA. Tratamento da miíase humana cavitária com ivermectina oral. Rev Bras Otorrinolaringol 2001;67:755-761.

4. Al-Ismaili M, Scully C. Oral myiasis: report of two cases. Int J Paediatr Dent 1995;5:177-179.

5. Ramalho JRO, Prado EP, Santos FCC, Cintra PPVC, Pinto JA Miíase nasal: Relato de caso. Rev Bras Otorrinolaringol 2001;67:581-584.

6. Mazza A. Tratamento das mí́ases pelo óleo canforado. Rev Bras Oto-Rino-Laringológica 1965;33:41.

7. Agrawal RD, Ahluwalia SS, Bhatia BB. Occurrence of Oestrus ovis larvae in nasal cavity of a woman. J Indian Med Assoc 1978;70:263 (letter).

8. Sharma H, Dayal D, Agrawal SP. Nasal myiasis: Review of 10 years experience. J Laryngol Otol 1989;103:489-491.

9. Martin-Prevel Y, Cosnefroy JI, Tshipampa P, Ngari P, Chodakewitz JA, Pinder M. Tolerance and efficacy of single high-dose ivermectin for the treatment of loiasis. Am J Trop Med Hyg 1993;48:186-192.

10. Chippaux JP, Bouchité M, Boussinesq M, Ranque S, Baldet S, Demanou M. Impact of repeated large scale ivermectin treatments on the transmission of loa-loa. Royal Soc Trop Med Hyg 1998;92:454-458.

11. Campbell WC. Ivermectin: An update. Parasitol Today 1985;1:10-16.

12. Jelinek T, Northdurft HD, Rieder N, Loscher T. Cutaneous myiasis: review of 13 cases in travelers returning from tropical countries. Int J Dermatol 1995;34:624-626.

13. Cabrera H, Pietro Paolo N, Arto G. Tratamiento de miiasis superficial com ivermectina. Act Terap Dermatol 1998;21:370-372.

14. MacDonald PJ, Chan C, Dickson J, Jean-Louis F, Heath A. Opthalmomyiasis and nasal myiasis in New Zealand: a case series. N Z Med J 1999;122:445-447.

15. Victoria J, Trujillo R, Barreto M. Myiasis: a successful treatment with topical ivermectin. Int J Dermatol 1999;38:142-144.

16. Duque SFL, Valderrama HR, Gonzalez RJ. Tratamiento de miasis oral con ivermectina. Notificación de tres casos causados por Cochliomyia hominivorax (Coquerel). Rev Fac Odontol Univ Ant 1998; 10:41-47. 